\title{
Exploring the relationship between Landsat- 8/OLI remote sensing reflectance and optically active components in the surface water at the UHE Maua/PR
}

\author{
Análise Exploratória da reflectância da água em imagem Landsat-8/OLI e \\ em componentes opticamente ativos coletados na água do Reservatório da \\ UHE Mauá/PR ${ }^{1}$
}

\author{
Adriana Castreghini de Freitas Pereira ${ }^{2}$ Evlyn M. L. de Moraes Novo ${ }^{3}$, \\ Jaqueline Aparecida Raminelli4
}

Recebido em abril de 2018. Aprovado em novembro de 2018.

\begin{abstract}
The quality and quantity of water available for both economic growth and life sustainability is one of the major challenges for the sustainable development in the 21 st century. This challenge requires research focused on the monitoring of time changes in water properties in several spatial scales. Satellite remote sensing has been applied as an alternative for providing information on optically active components, which act as indicators of water quality. Satellite remote sensing performance, however, varies from one aquatic system to another depending on several factors, such as size, depth, optical properties. This study, therefore, aims to explore the viability of applying remote sensing for monitoring the UHE Mauá reservoir, located in Paraná State. For that, an experiment was carried out to obtain water samples at 24 random samples distributed into the reservoir. Those samples were analyzed in laboratory and optically active components, namely, total suspended solids (TSS) and chlorophyll-a (Chl-a) concentration determined. Surface remote sensing reflectance provided by Landsat/OLI images almost concurrently to satellite overpass was computed for each sample in order to assess the best set of spectral bands and/or band combinations for estimating the concentrations of TSS and Chla. This avaliation was performed through the linear correlation and the factor analysis.Results indicate that Chl-a was the optically active component spanning the widest range of variability in the Mauá reservoir and having the highest potential to be estimated using remote sensing OLI
\end{abstract}

\footnotetext{
1 Departamento de Geociências, Programa de Pós-Graduação em Geografia - PPGG - Universidade Estadual de Londrina, UEL, Londrina/PR, Brazil. adrianacfp@uel.br;adricfp@gmail.com 2 Instituto Nacional de Pesquisas Espaciais - INPE, São José dos Campos/SP, Brazil. evlyn.novo@inpe.br

3 Departamento de Estatística, Universidade Estadual de Londrina, UEL, Londrina/PR, Brazil. jaqest@gmail.com
} 
band 3 (green),being able to explain more than $70 \%$ from the concentration of chlorophyll-a, with the analysis of linear correlation, and being able to explain more than $90 \%$ from the concentration of chlorophyll-a, with the factor analysis, in conjunction with other bands OLI.

KEYWORDS: Landsat-8/OLI. Chl-a. TSS.

\section{RESUMO}

A qualidade e a quantidade de água potável disponível tanto para crescimento econômico quanto para sustentabilidade da vida é um dos maiores desafios para o desenvolvimento sustentável no século XXI. Este desafio exige pesquisas focadas no acompanhamento de alterações nas propriedades da água em várias escalas espaciais. O sensoriamento remoto orbital tem sido aplicado como uma alternativa para o fornecimento de informações sobre componentes opticamente ativos, que funcionam como indicadores da qualidade da água. A performance do sensoriamento remoto orbital, contudo, varia de um sistema aquático para outro, dependendo de vários fatores, tais como tamanho, profundidade, propriedades ópticas. Este estudo, portanto, pretende explorar a viabilidade da aplicação de sensoriamento remoto para o monitoramento do reservatório da UHE Mauá, localizado no estado do Paraná. Para tanto, foi realizado um experimento com 24 amostras aleatórias de água distribuídas no reservatório. Tais amostras foram analisadas em laboratório e a concentração de componentes opticamente ativos, ou seja, total de sólidos em suspensão (TSS) e clorofilaa (Chl a) foi determinada. A reflectância do sensoriamento remoto de superfície fornecida pelas imagens Landsat/OLI, tomadas quase simultaneamente a coleta de dados em campo foi calculada para cada amostra a fim de avaliar o melhor conjunto de bandas espectrais e/ou combinações de bandas para estimar as concentrações do TSS e Chl-a. Essa avaliação foi realizada através das análises de correlações lineares e da análise fatorial.Os resultados indicam que Chl-a foi o componente opticamente ativo que abrangeu a mais ampla gama de variabilidade no reservatório Mauá e tem o maior potencial para ser estimado usando a banda OLI 3 (verde), explicando mais de $70 \%$ da concentração de clorofilaa, no caso da análise das correlações lineares e explicando mais de $90 \%$ da concentração de clorofila-a, no caso da análise fatorial, combinada com outras bandas OLI.

PALAVRAS-CHAVE:Landsat-8/OLI. Clorofila-a - Chl-a. Total de Sólidos em Suspensão-TSS.

Introduction

Hydroelectrical reservoirs can be thought as an aquatic system with transient properties between rivers and lakes depending on the interplay between catchment basin geomorphology, hydrological regime and water withdraw demand. Roughly, reservoirs have a river-like zone at the entrance 
of the main river, a lotic zone near the dam, and a transition zone between them (TUNDISI, J.G. and MATSUMURA-TUNDISI, T., 2003). Reservoirs water properties depend on the sources of pollution within the catchment basin, in which main sources of pollution are urban and industrial effluents and fertilizers from agriculture (MARTINELLI and FILOSO, 2008).

A new generation of satellites, including Landsat/OLI, with improved radiometric resolution and signal-to-noise ratio (SNR) has opened the opportunity for the development of remote sensing products such as total suspended solid and chlorophyll-a concentration which can be used into water quality models (DORJI and FEARNS, 2017; DORNHOFER et al, 2016; SANDERDE CARVALHO et al., 2015; PALMER et al, 2015). Several studies have also reported successful application of satellite images for assessing gold mining impacts on water silting of Tapajós River tributaries (LOBO et al., 2016). There has been a great deal of scientific and methodological advances in the impact of the optically active components (OAC) on the water and on the measurements of inherent optical properties and on their implications for the application of satellite images in water studies (VERPOORTE, 2014; HAMBRIGHT, 2014; GIARDINO et al., 2014; OLMANSON et al., 2013; ROESSLER et al., 2013; McCULLOUGH et al., 2012; NAS et al., 2008; SIMIS et al., 2005).

Both, chlorophyll-a (Chl-a) and total suspended solids (TSS) concentration in the water are biological and physical parameters currently in use to assess water quality. Chlorophyll-a concentration usually is used as proxy of phytoplankton abundance, since it is a photosynthesizer pigment common to all species (REYNOLDS, 1984). Chl-a absorption bands in $438 \mathrm{~nm}$ and $676 \mathrm{~nm}$ are responsible for changes in water color, causing an increase in the green reflectance as the pigment concentration giving similar boundary conditions of the aquatic system (WEAVER and WRIGLEY, 1994). TSS concentration is defined as a set of suspended particles smaller than $45 \mu \mathrm{m}$, being generally dominated by inorganic matter, which is responsible for a monotonic increase in the reflectance with the increase in concentration 
(MOBLEY, 1994). Another peculiar aspect of the TSS spectral reflectance is the continuous shift of the reflectance towards longer wavelengths as the concentration increases (CURRAN andNOVO, 1988).

This research contributes towards transforming satellite images in operational tools for monitoring the water quality of the UHE Mauá reservoir. For that, the authors carried out an experiment at the reservoir in order to assess the relationship between remote sensing reflectance (Rrs) measured with Landsat/ OLI images and the concentrations of TSS and Chl-a, through the analysis of correlation and linear regression. This exploratory analysis is the first step towards assessing the viability of using those images for controlling Mauá reservoir water quality.

\section{Study Area}

The study area - UHE Mauá/PR Reservoir (Figure 1), is located on the Tibagi River basin, upstream of Salto Maua and belongs to the TelêmacoBorba and Ortigueira municipalities, Paraná State. It is a relatively new reservoir which started operating in December, 2012. Tibagi basin land cover was originally composed of different forest types but much of that has been changed to a mixture of extensive pastures with larger or smaller remnants of forest and forest regrowth (LACTEC, 2009). Basin natural setting and human impact on the vegetation is a key aspect in the state of degradation of the remaining forest and of the soil organic matter, mainly in the floodplains. The current catchment basin setting is highly threatening to the water quality of the Mauáreservoir which receives and processes the basin output.

Londrina city meets $100 \%$ of this urban population water supply system relying on two systems, one of them, the Tibagi River which contributes to the UHE Mauá with a total of $4.500 \mathrm{~m}^{3} / \mathrm{h}$ of total (PMSB, 2008). It is the largest center surrounded by a cluster of industrialized cities which responds for more than $50 \%$ of the domestic and industrial waste. In addition 
to that, agricultural land uses respond for high volumes of pesticides and fertilizers representing an important source of non-point pollution to the reservoir mainly in areas of soybean and Pinus (PEREIRA and SCROCCARO, 2010).

Figure1 - Study Area.

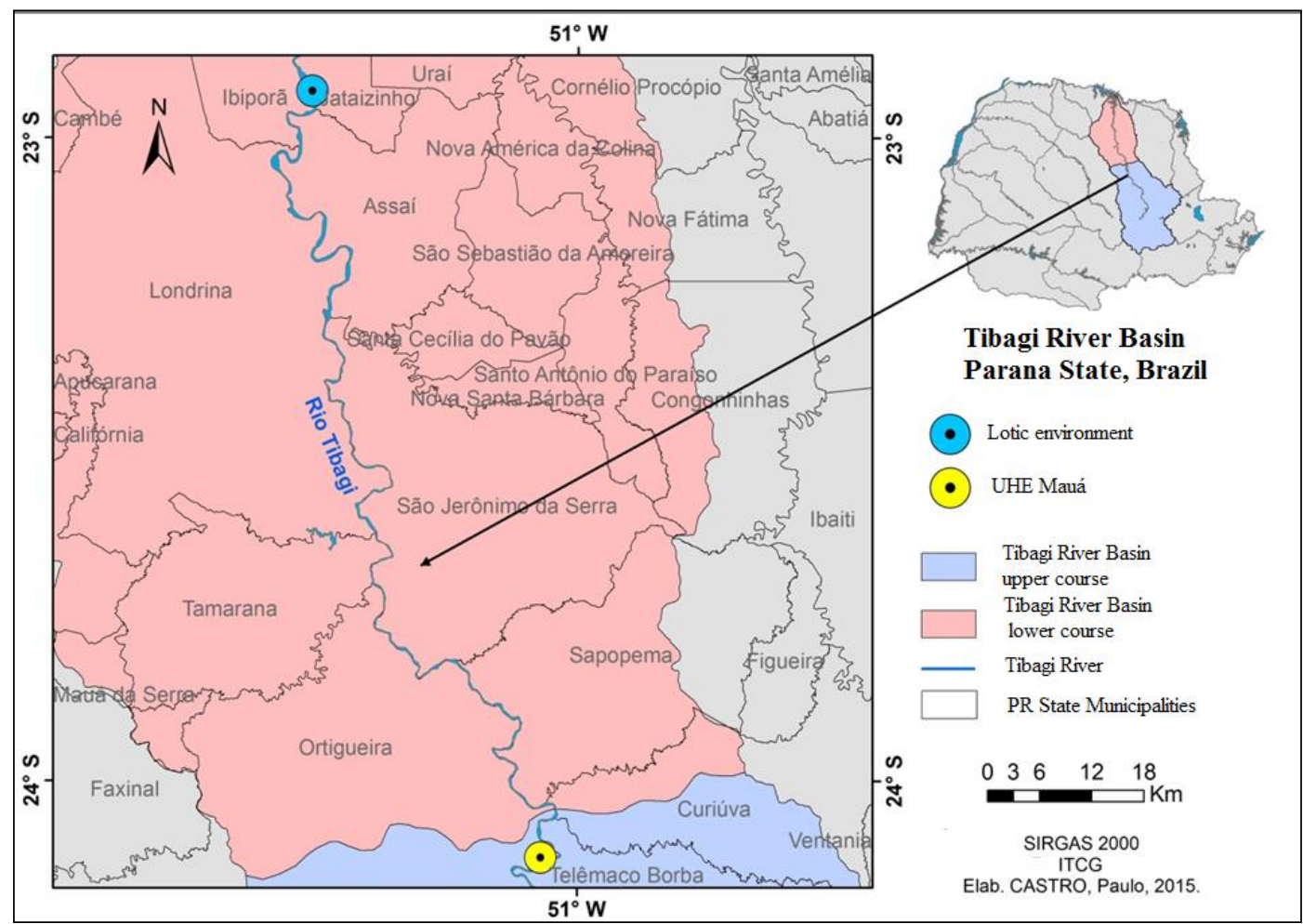

Source: Castro, P.H.M.; Pereira, A.C.F.; Barros, M.V.F. (2017)

\section{Data Acquisition and Methods}

\subsection{Ground data acquisition}

Ground data acquisition at Mauá/PR was carried out in July, 9th, 2016, during the dry season, at Secchi Depth (m). In this study, the authors focused only on Chl-a, TSS and Turbidity. Data on weather condition, sampling time, GPS location at each sampling station were also acquired. 
The authors adopted a systematic sampling design for convenience (not probabilistic). The reservoir was first stratified into regions according to the rates of time changes in water spectra assessed with OLI images acquired in the previous year. The number of sample stations decreased from the areas with high spectral variability in time to areas characterized by small spectral variability in time (THOMPSON, 2002; PEREIRA, 2015; 2008). The sampling strata were established as concentric $500 \mathrm{~m}$ bands relative to the reservoir central area (CASTRO, 2017). A total of 24 sampling stations was distributed in the UHE Mauá reservoir (Figure 2). Data collection was carried out between 9:00 am and 14:00 pm with clear skies and weak winds. Data acquisition in each sampling site lasted in average 5 minutes.

Figure 2 - Sampling design and sampling station distribution.

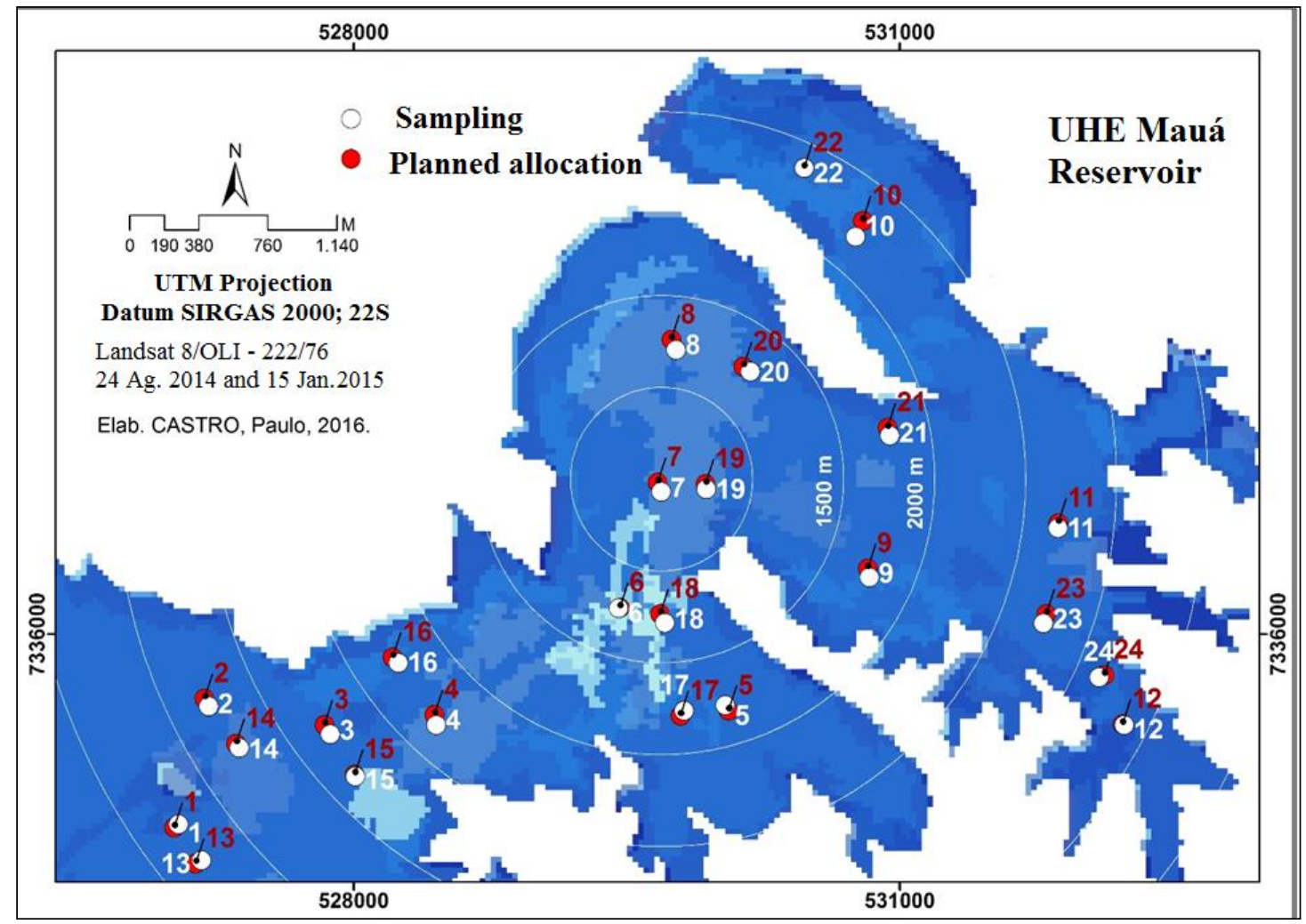

Source: Castro, P.H.M.; Pereira, A.C.F.; Barros, M.V.F. (2017)

Logistical constraints prevented in situ data collection concurrently to satellite data acquisition. Therefore, Landsat/OLI images were acquired 
quasi-simultaneously to ground data, on July, 12th, 2016, with a delay of 3 days in relation to ground data acquisition. During the ground mission, Van Dorn bottle stopped working causing water samples at some of the stations to be collected at $30 \mathrm{~cm}$.

Water samples were preserved and immediately taken to the laboratory for component determination. Turbidity was measured on site. Table 1 summarizes the methods and equipment used for water samples processing.

Table 1 - Method and equipment used for determination of Mauá Reservoir limnological properties in the present study.

\begin{tabular}{|c|c|c|c|}
\hline VARIABLE & $\begin{array}{l}\text { REF. } \\
\text { APHA } \\
, \\
\text { AWW } \\
\text { A, } \\
\text { WEF } \\
(2012)\end{array}$ & METHOD & $\begin{array}{l}\text { EQUIPMENT(MODEL/TRA } \\
\text { DE NAME) }\end{array}$ \\
\hline $\begin{array}{l}\text { Chlorophyll- } \\
a \\
\left(\mu \mathrm{g} \mathrm{L}^{-1}\right)\end{array}$ & $\begin{array}{l}10200 \\
\mathrm{H}\end{array}$ & $\begin{array}{l}\text { Spectrofotomet } \\
\text { er with } \\
\text { extraction in } \\
\text { acetone } 90 \%\end{array}$ & $\begin{array}{l}\text { Spectrofotometer: Macherey- } \\
\text { Nagel - MN Nanocolor vis } \\
919150\end{array}$ \\
\hline $\begin{array}{l}\text { Solids } \\
\left(\mathrm{mg} \mathrm{L} \mathrm{L}^{-1}\right)\end{array}$ & $\begin{array}{l}2540 \\
B, C \\
D \text { e E }\end{array}$ & $\begin{array}{l}\text { Gravimetricde } \\
\text { termination }\end{array}$ & $\begin{array}{l}\text { Membranes } 1,2 \text { Mufla } 550^{\circ} \mathrm{C} \text { : } \\
\text { FORNITEC } 1940 \text { Stove } 103^{\circ} \mathrm{C} \text { : } \\
\text { LUFERCO }\end{array}$ \\
\hline $\begin{array}{l}\text { Temperatur } \\
\text { e }\left({ }^{\circ} \mathrm{C}\right)\end{array}$ & $\begin{array}{l}2550 \\
B\end{array}$ & $\begin{array}{l}\text { ElectronicTher } \\
\text { mometer }\end{array}$ & Hach HQ 30d \\
\hline $\begin{array}{l}\text { Turbidity } \\
\text { (NTU) }\end{array}$ & $\begin{array}{l}2130 \\
\mathrm{~B}\end{array}$ & $\begin{array}{l}\text { NefolometricM } \\
\text { ethod }\end{array}$ & Hach 2100Q \\
\hline
\end{tabular}

Source: Elaborated by the authors (2018)

3.2 Remote sensing data processing 
Landsat/OLI images were acquired at [https://earthexplorer.usgs.gov] as orthorectified surface reflectance (Table 2).

Table 2 - Landsat/OLI data

\begin{tabular}{c|c}
\hline BANDS & $\begin{array}{c}\text { WAVELENGTH } \\
\text { RANGES (nm) }\end{array}$ \\
\hline 1 & $430-450$ \\
\hline 2 & $450-510$ \\
\hline 3 & $530-590$ \\
\hline 4 & $640-690$ \\
\hline 5 & $850-880$ \\
\hline 6 & $1,570-1,650$ \\
\hline 7 & $2,110-2,290$ \\
\hline
\end{tabular}

The 24 ground sampling stations were located on the images using their UTM coordinates. The samples were examined with the aid of color composites to assess image quality regarding adjacent effects derived from cloud cover scattering, cloud shadow, among others.

After this careful screening, three samples were discarded (stations 1, 2 and 13) due to poor image quality around the stations. The remote sensing reflectance (Rrs) of the average of $3 \times 3$ pixels around the sample station was acquired and submitted to an exploratory analysis described in the next section.

\subsection{Exploratory Analysis}


The exploratory analysis consisted of plotting all in situ variables against the Rrs in diagnostic bands and combination of bands recommended in the literature (GITELSON et al., 1986; MITTENZWEY and GITELSON, 1988; MITTENZWEY et al., 1992; GITELSON, 1992; GITELSON, 1993; DEKKER, 1993; DEKKER and PETERS, 1993; KIRK, 1994; GITELSON et al., 1995; RUNDQUIST, 1996; SCHALLES and YACOBI, 2000). Chl-a concentration, for instance, was plotted against the reflectance at the band corresponding to the scatter by phytoplankton cells in the visible spectra, the green region (B3). TSS and Turbidity were plotted against the red and nearinfrared bands (B4 e B5). The exploratory analysis allowed to distinguish the existence of at least two optically distinct water masses in the reservoir during the dry season.

Based on the exploratory analyze, the data was evaluated in two different criteria. First, sample stations were divided into distinct water masses and then submitted to linear correlation analyses between the limnological variables and the Rrs. Before selecting the best set of OLI bands and combination of bands as input to empirical models, the authors set a threshold such that coefficient of explanation, $R^{2} \geq 0,70$ and $p$ - value $\leq 0,01$.In a second moment,sample stations were divided into distinct water masses using factor analyzes via main components.

All statistical analysis were performed using the software R (2018).

\section{Results}

4.1 Correlation and multiple linear regression analysis

In situ data (Table 3) indicates that Chl-a was the optically active component spanning the widest range of variability in the Mauá reservoir, with the maximum concentration reaching around 5 times the minimum, being responsible for the optically distinct water masses.

Table 3. Limnological variable statistics 


\begin{tabular}{l|c|c|c|c|c|c}
\hline $\begin{array}{l}\text { LimnologicalVar } \\
\text { iables }\end{array}$ & $\begin{array}{l}\text { Mea } \\
\mathbf{n}\end{array}$ & $\begin{array}{l}\text { Medi } \\
\text { an }\end{array}$ & $\begin{array}{l}\text { Maxim } \\
\text { um }\end{array}$ & $\begin{array}{l}\text { Minim } \\
\text { um }\end{array}$ & $\begin{array}{l}\text { Standa } \\
\text { rd } \\
\text { Deviati } \\
\text { on }\end{array}$ & $\begin{array}{l}\text { CoefficientofVar } \\
\text { iation }\end{array}$ \\
\hline $\begin{array}{l}\text { Chlorophyll-a } \\
(\boldsymbol{\mu g} / \mathbf{L})\end{array}$ & 9,68 & 7,09 & 20,91 & 3,89 & 5,62 & $58,0 \%$ \\
\hline TSS (mg/L) & 1,74 & 1,80 & 2,50 & 0,10 & 0,55 & $31,6 \%$ \\
\hline Turbidity (NTU) & 6,80 & 6,84 & 7,25 & 5,99 & 0,35 & $5,1 \%$ \\
\hline Secchi (m) & 1,05 & 1,05 & 1,20 & 0,80 & 0,10 & $9,5 \%$ \\
\hline
\end{tabular}

Source: Elaborated by the authors (2018)

It was observed in exploratory and correlation analyses the occurrence of two distinct patterns, the first named cluster 1 where the increased concentration of chlorophyll-a corresponds to a discrete increase in reflectance in the green; and a second pattern, cluster 2 where water reflectance increases as the concentration of chlorophyll-a decreases. Such distinct patterns suggest that there are water bodies with distinct optical behavior. A new exploratory analysis was carried out for samples in each cluster and the possible outliers excluded from the analyses (6 points). Therefore, the subsequent analysis were carried out for each cluster independently free from spurious measurements.

Despite the limited number of samples remaining for analyses (cluster $1, \mathrm{n}=5$ and cluster $2, \mathrm{n}=10$ ) there was a reasonable increase in $\mathrm{R}^{2}$ value for cluster $2\left(R^{2}=0,73\right)$. For cluster 1 , however, these steps did not work out. Table 4 shows the limnological variables concentration for cluster 2 and Figure 3 presents the dispersion pattern of B3 reflectance in relation to chlorophyll-a concentration. Figure 3 results suggests that B3 has potential for monitoring chlorophyll-a variability in the Mauá reservoir since changes in reflectance explains more than $70 \%$ of the variability in chlorophyll-a concentration (that is to say, that chlorophyll-a concentration variation causes a decrease in B3 reflectance) $\left(R^{2} \geq 0,70\right.$ and $p$-value $\left.\leq 0,01\right)$. 
Table 4 - Sample points, cluster $2, \mathrm{n}=10$

\begin{tabular}{|c|c|c|c|c|c|c|c|c|}
\hline $\begin{array}{c}\text { Sample } \\
\text { Points }\end{array}$ & $\begin{array}{l}\text { Secchi } \\
\text { (m) }\end{array}$ & $\begin{array}{l}\text { Turbidity } \\
\text { (NTU) }\end{array}$ & $\begin{array}{c}\text { TSS } \\
(\mathrm{mg} / \mathrm{L})\end{array}$ & $\begin{array}{l}\text { Chlorophyll- } \\
\text { a }(\mu \mathrm{g} / \mathrm{L})\end{array}$ & $\begin{array}{c}\text { Temperature } \\
\left({ }^{\circ} \mathbf{C}\right)\end{array}$ & $\begin{array}{l}\text { Collection } \\
\text { time }\end{array}$ & $\begin{array}{c}\text { Sky } \\
\text { conditions }\end{array}$ & $\begin{array}{l}\text { Wind } \\
\text { Wave }\end{array}$ \\
\hline 3 & 1,05 & 7,24 & 1,90 & 6,12 & 20,6 & $12: 40$ & Sun & $\begin{array}{l}\text { weak / } \\
\text { withoutwave }\end{array}$ \\
\hline 10 & 1,10 & 6,57 & 1,70 & 10,65 & 18,3 & $13: 44$ & Sun & $\begin{array}{l}\text { weak / } \\
\text { withoutwave }\end{array}$ \\
\hline 11 & 1,00 & 6,70 & 1,40 & 7,14 & 19,9 & $14: 03$ & Sun & $\begin{array}{l}\text { weak / } \\
\text { withoutwave }\end{array}$ \\
\hline 12 & 1,05 & 6,83 & 1,90 & 4,75 & 19,9 & $12: 55$ & Sun & $\begin{array}{l}\text { weak / } \\
\text { withoutwave }\end{array}$ \\
\hline 14 & 1,10 & 7,08 & 1,90 & 7,10 & 19,5 & $12: 49$ & Sun & $\begin{array}{l}\text { weak / } \\
\text { withoutwave }\end{array}$ \\
\hline 19 & 1,10 & 7,07 & 2,50 & 12,83 & 18,7 & 10:59 & Sun & $\begin{array}{l}\text { weak / } \\
\text { withoutwave }\end{array}$ \\
\hline 20 & 1,05 & 6,66 & 1,30 & 14,07 & 18 & 10:20 & Sun & $\begin{array}{l}\text { weak / } \\
\text { withoutwave }\end{array}$ \\
\hline 22 & 1,20 & 6,63 & 1,70 & 10,73 & 18,8 & 09:36 & Sun & $\begin{array}{l}\text { weak / } \\
\text { withoutwave }\end{array}$ \\
\hline 23 & 1,20 & 6,23 & 1,60 & 4,53 & 20,3 & $13: 52$ & Sun & $\begin{array}{l}\text { weak / } \\
\text { withoutwave }\end{array}$ \\
\hline 24 & 1,20 & 6,62 & 0,10 & 3,89 & 20,1 & $13: 59$ & Sun & $\begin{array}{l}\text { weak / } \\
\text { withoutwave }\end{array}$ \\
\hline
\end{tabular}

Source: Elaborated by the authors (2018)

Table 4 shows that the points belonging to cluster 2 have similar limnological characteristics, specially in relation to the optical data.

Figure 3 - Dispersion from Band 3/OLI Reflectance according to Chlorophyll-a concentration, cluster $2, \mathrm{n}=10$ 


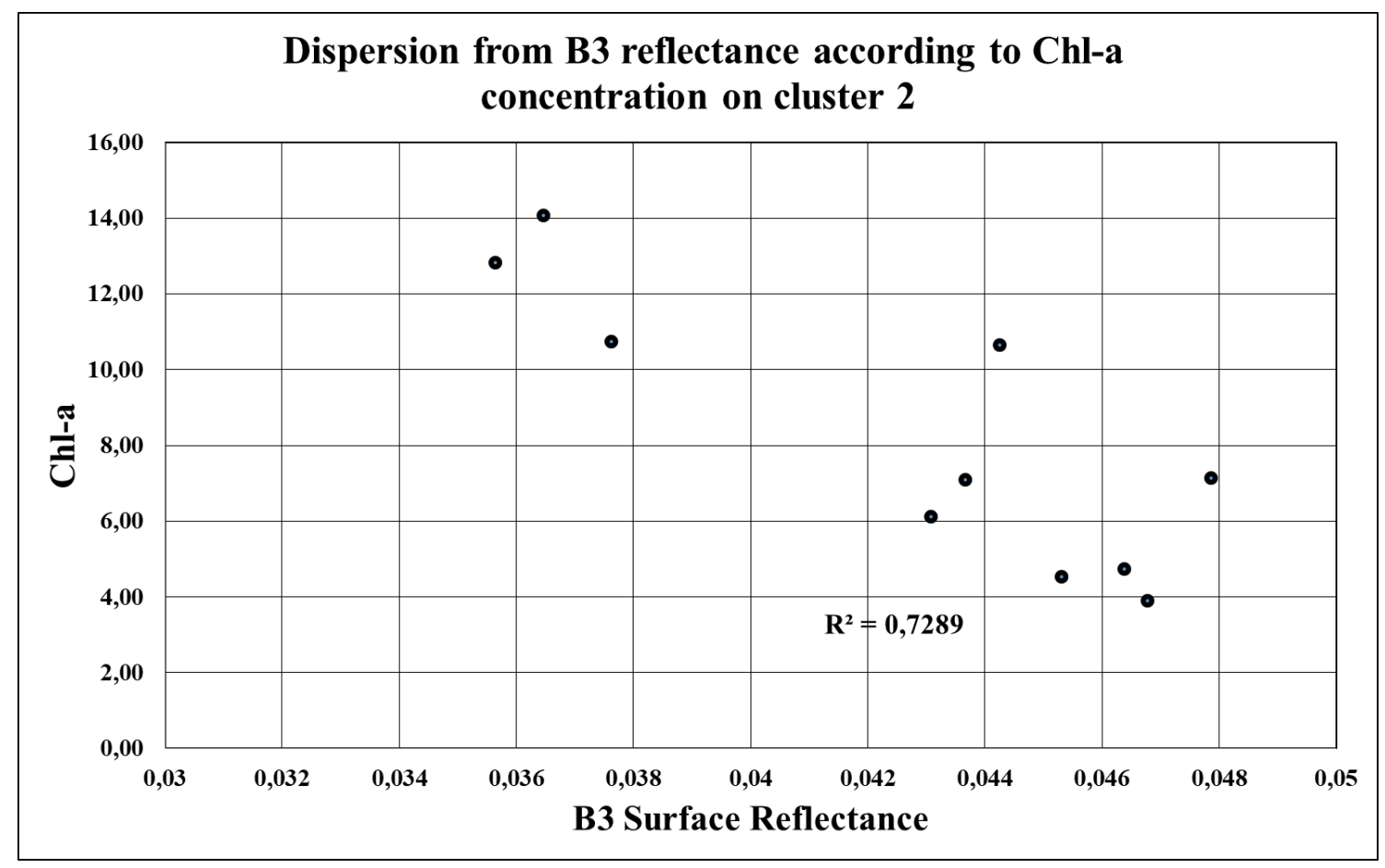

Source: Elaborated by the authors (2018)

Pearson linear correlation analysis results for cluster 2 for all OLI bands (table 5) show that despite the limited number of samples and the delay between ground data and image acquisitions, all OLI bands are highly correlated with chlorophyll-a concentration, but only bands 3 and 4 meet authors requirements.

Table 5 - Linear Correlation Analysis between Bands/OLI and data collected in situ -

Pearson Correlation and p-value

\begin{tabular}{l|l}
\hline Bands & Chl-a \\
\hline B1 & $-0,794$ \\
& 0,006 \\
\hline B2 & $-0,806$ \\
& 0,005 \\
\hline B3 & $-0,854$ \\
& 0,002 \\
\hline B4 & $-0,845$ \\
& 0,002 \\
\hline B6 & $-0,763$ \\
& 0,010 \\
\hline
\end{tabular}

Source: Elaborated by the authors (2018) 
Pearson linear correlation analysis (Table 6) shows that band combinations did not outperformed the use of Band 3. Despite de limited number of samples, all the correlations are significant ( $p$-value $<0,01$ ), but the proportion of variance 'explained' by any model based on those bands would not meet authors requirement $\left(R^{2} \geq 0,70\right)$.

Table 6 - Linear Correlation Analysis between /OLI bands combination and in situ Chl-a (Pearson Correlation and p-value) - Cluster 2

\begin{tabular}{|c|c|}
\hline BandsCombinations & Chl-a \\
\hline B3/B4 & $\begin{array}{l}0,801 \\
0,005\end{array}$ \\
\hline B5/B4 & $\begin{array}{l}-0,768 \\
0,009\end{array}$ \\
\hline B4/B3 & $\begin{array}{l}-0,797 \\
0,006\end{array}$ \\
\hline$(\mathrm{B} 3-\mathrm{B} 4) /(\mathrm{B} 3+\mathrm{B} 4)$ & $\begin{array}{l}0,799 \\
0,006\end{array}$ \\
\hline (B3-B5)/(B3+B5) & $\begin{array}{l}0,770 \\
0,009\end{array}$ \\
\hline B4/B2 & $\begin{array}{l}0,840 \\
0,002\end{array}$ \\
\hline B2/B3 & $\begin{array}{l}-0,798 \\
0,006\end{array}$ \\
\hline
\end{tabular}

4.2 Factor analysis via main components

From the matrix of the linear correlation between the concentration of chlorophyll-a and the Landsat bands 8/OLI, of 21 available sampling points, it was obtained the two first factors and the factorial load estimated via main components analysis.

The input bands were defined as: B1; B2; B3; B4; B5; B6; B7 and combination of bands: $\mathrm{B} 8=\mathrm{B} 4 / \mathrm{B} 3 ; \quad \mathrm{B} 9=(\mathrm{B} 3-\mathrm{B} 4) /(\mathrm{B} 3+\mathrm{B} 4) ; \quad \mathrm{B} 10=(\mathrm{B} 3-$ $\mathrm{B} 5) /(\mathrm{B} 3+\mathrm{B} 5) ; \mathrm{B} 11=\mathrm{B} 4 / \mathrm{B} 5 ; \mathrm{B} 12=\mathrm{B} 4 / \mathrm{B} 2 ; \mathrm{B} 13=\mathrm{B} 2 / \mathrm{B} 3 ; \mathrm{B} 14=\mathrm{B} 2 / \mathrm{B} 5 ; \mathrm{B} 15=\mathrm{B} 5 / \mathrm{B} 1$; $\mathrm{B} 16=\mathrm{B} 3 / \mathrm{B} 4 ; \mathrm{B} 17=\mathrm{B} 6 / \mathrm{B} 5 ; \mathrm{B} 18=\mathrm{B} 5 / \mathrm{B} 4$. 
In order to indentify dispersion patterns from the observation and a probable grouping of the sampling stations, it was gereated a biplot graphic, also known as percepcion map.

Figure 4:PCA Biplot

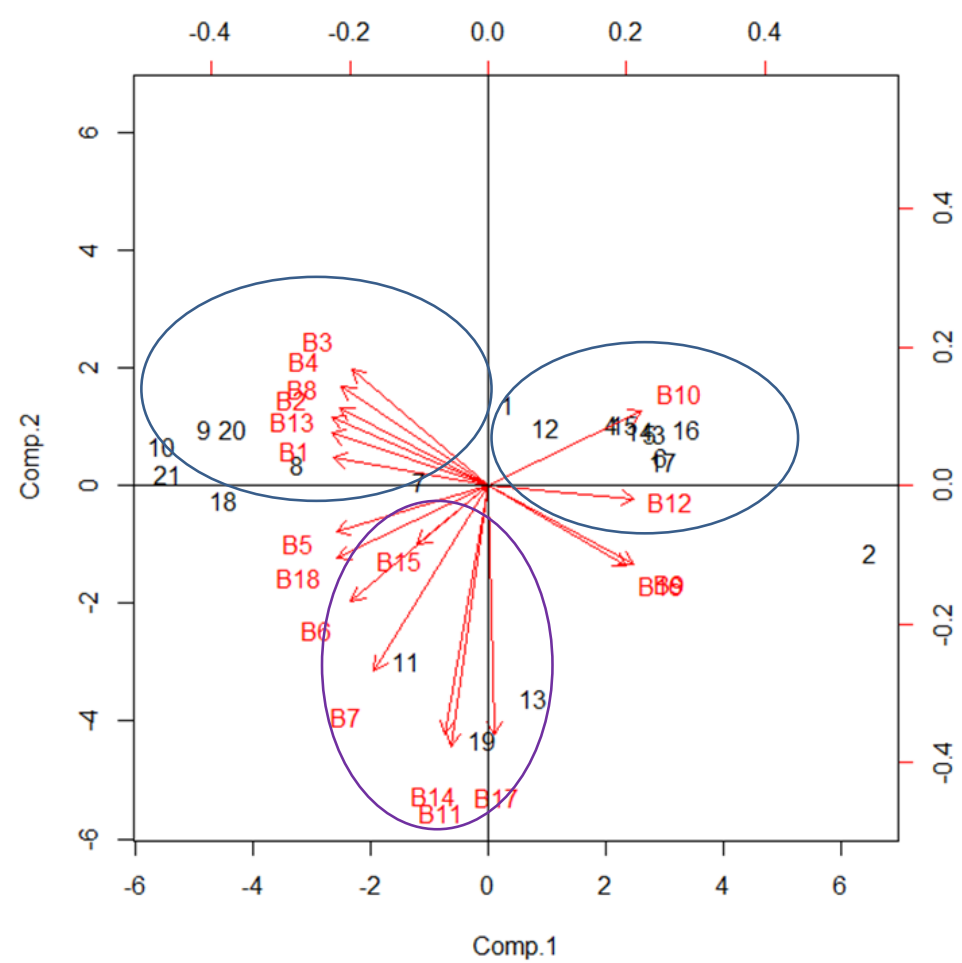

Source: Elaborated by the authors (2018)

It's possible to see in the figure 4 three possible clusters or point grouping, in order of bands from Landsat-8/OLI. This are resumed in table 7.

Table 7 - Clusters of sampling or point grouping in order from Landsat-8/OLI

\begin{tabular}{l|l|l|l}
\hline & CLUSTER 1 & CLUSTER 2 & CLUSTER 3 \\
\hline POINTS & $\begin{array}{l}7,8,9,10,18,20, \\
21\end{array}$ & $\begin{array}{l}1,2,3,4,5,6,12, \\
14,15,16,17\end{array}$ & $11,13,19$ \\
\hline BANDS & B1, B2, B3, B4, & B10, B12 & B7, B11, B14, B17 \\
& B5, B8, B13 & & \\
\hline
\end{tabular}

Source: Elaborated by the authors (2018) 
For each cluster was adjusted a factor model. Only for cluster $1(n=7)$ data it was obtained statistical significance ( $p$-value $<0,01$ ), being the predictive power from the adjusted and presented model in equation 1 of approximately 93\%.As in the previous results, the resulting model is written as a linear combination between the B4 and B3 bands, what possibly show a strong relation between B3 OLI and Chlorophyll-a in the waters of UHE Mauá/PR.

$$
Y=-20,53+3334,62 * B 4-135,47 * B 13
$$

Being $B 13=\left(\frac{B 2}{B 3}\right)$

\section{Discussions}

Despite the experimental limitations due to the limited number of samples, problems with the Van Dorn bottle and delay between in situ data collection and OLI image acquisition, the results show that the green reflectance (B3) can be used to monitor chlorophyll-a concentration in the UHE Mauá Reservoir. The factor model generated from the main components analysis, confirm the hypothesis related to $\mathrm{B} 3$, once the explanation coefficient is superior to $90 \%$ and meets the required assumption, although the sample size is relatively small. It is important, however, to highlight that more experiments are needed in order to cover a wider range of chlorophyll-a concentration and also the information on the vertical distribution of chlorophyll-a concentration in the water column as pointed out by Barbosa et al. (2016).

It is important to highlight, however, that B3 performance might be an artifact of the explanatory analyses used to split the clusters. This aspect should be investigated further in the next steps of this research as well;besides the spatialization of the generated factor model of Chlorophyll-a 


\section{Conclusions}

The exploratory and linear correlation analysesindicated that Landsat/OLI band 3 can be applied to estimate chlorophyll-a concentration in the Mauá reservoir. Due to the small sample size, however, it is highly recommended that more experiments be carried out in different seasons and using different sampling designs before satellite images can be used operationally. The exploratory analyses proved to be quite useful to identify the existence of optically distinct water masses in the Mauá Reservoir, which should be taken into account in the monitoring of this reservoir.The model of regression generated for chlorophyll-a in the waters of UHE Mauá/PR demonstrated the applicability of this research on the inference of water quality parameters with orbit remote sensing.

\section{References}

BARBOSA, C.C.F. "Sensoriamento Remoto da dinâmica da circulação da água do sistema planície de Curuai/Rio Amazonas."São José dos Campos, 2005, 281 f. Tese de Doutorado em Sensoriamento Remoto - INPE, São José dos Campos.

CASTRO, P.H.M.; PEREIRA, A.C.F.; BARROS, M.V.F. ModelagemAmostralpara o Monitoramento de componentes opticamente ativos no Rio Tibagi/PR, utilizando imagens Landsat 8/OLI. Revista Brasileira de Cartografia, 2017, n 69/7: pp. 1231-1246.

CASTRO, P. H.M.“Potencial das Imagens Landsat 8/OLI na detecção de componentes opticamente ativos no Rio Tibagi, PR.” Londrina, 2017, 78f. Tese de Doutorado em Geografia - UEL, Londrina.

CURRAN, P.J.; NOVO, E.M.M. “The relationship between suspended sediment concentration and remotely sensed spectral radiance: a review.” Journal of Coastal Research, v.4, n.3, 1988, pp.351-368. 
DEKKER, A G. "Detection of optical water quality parameters for eutrophic waters by high resolution remote sensing", 1993, $211 \mathrm{f}$. $\mathrm{PhD}$ theses of Free University, Amsterdam.

DEKKER, A.G.; PETERS, S.W.M. The use of the thematic mapper for the analysis of eutrophic lakes: a case study in the Netherlands. International Journal of Remote Sensing, v. 14, n. 5, 1993, pp. 799-821.

DORJI, P.; FEARNS, P. "Impact of the spatial resolution of satellite remote sensing sensors in the quantification of total suspended sediment concentration: A case study in turbid waters of Northern Western Australia."PLoS ONE; Public Library of Science, v. 12, n.4.,2017, (https://www.ncbi.nlm.nih.gov/pmc/articles/PMC5381897/).

DORNHOFER, K; GORITZ, A.; GEGE, P.; PFLUG, B; OPPELT, N. 'Water constituents and water depth retrieval from Sentinel-2A - A first evaluation in a oligotrophic lake.” Remote Sensing, v.8, n. 941, 2016, pp. 1-25. (www.mdpi.com/journal/remotesensing).

GIARDINO, C. BRESCIANI, M., CAZZANIGA, I., SCHENK, K., RIEGER, P., BRAGA, F., MATTA, E., BRANDO, V.E."Evaluation of Multi-Resolution Satellite Sensors for Assessing Water Quality and Bottom Depth of Lake Garda". Sensors, 14, 2014, pp. 24116-24131.

GITELSON, A.; NICANOROV, A.; SABO, G.; SZILAGYI, F. Etude de laqualite dês eaux de surface par teledetection. IAHS Publications 157: 1986, pp. 111-121.

GITELSON, A.A.The peak near $700 \mathrm{~nm}$ on radiance spectra of algae and water: relationships of its magnitude and position with chlorophyll concentration. International Journal of Remote Sensing, v. 13, 1992, pp. 3367-3373,

GITELSON,A.A.; GARBUZOV, G., SZILAGYI, F.; MITTENZWEY, K.H.,KARNIELI, A.; KAISER, A. Quantitative remote sensing methods for real time monitoring of inland waters quality. International Journal of Remote Sensing, v. 14, 1993, pp. 1269-1295.

GITELSON, A.; LAORAWAT, S.; KEYDAN, G.; VONSHAK, A. Optical properties of dense algal cultures outdoors and its application to 
remote estimation of biomass and pigment concentration in Spirulina platensis. Journal of Phycology, v. 31, n.5, 1995, pp. 828-834.

HAMBRIGHT, K.D., XIAO, X., DZIALOWSKI, A.R. "Remote Sensign of WQ and harmful algae in OK Lakes". Remote Sensing of Environment, 2, 2014, pp. 100-120.

KIRK, J.T.O. "Light \& Photosynthesis in aquatic ecosystems".Cambridge University Press, 1994, 509p.

LACTEC - Instituto de Tecnologia para o Desenvolvimento. "Modelagem Matemática da Qualidade da Água Para UHE Mauá”.Curitiba.

LOBO, F.L., COSTA, M.P., NOVO, E.M. (2016). "Time-series analysis of Landsat-MSS/TM/OLI images over Amazonian waters impacted by gold mining activities". Remote Sensing of Environment, 157, 2009, pp. 170-184.

MARTINELLI, L. A., and FILOSO, S."Expansion of sugarcane ethanol production in Brazil: environmental and social challenges". Ecological Applications, 18(4), 2008, pp. 885-898.

McCULlOUGH, I. A., LOFTIN, C.S., SADER, S.A. "Combining lake and watershed characteristics with Landsat TM data for remote estimation of regional lake clarity". Remote Sensing of Environment, 123, 2012, pp. 109-115.

MITTENZWEY, K.; GITELSON, A.In-situ monitoring of water quality on the basis of spectral refelctance. Int. RebueGes. Hydrobiol. 73, 1988, pp. 61-72.

MITTENZWEY, K.H.; GITELSON, A.A.; ULLRICH, S.; KONDRATYEV, K.Y.Determination of chlorophyll-a of inland waters on the basis of spectral reflectance. Limnology and Oceanography, v. 37, 1992, pp.147149.

MOBLEY, C. D. "Light and water: radiative transfer in natural waters". Academic Press. 1994.

NAS, B et al. "Mapping chlorophyll-a through in-situ measurements and Terra ASTER satellite data”. EnvironMonitAssess, 157, 2009, pp. 375382. 
NOVO, E.M.L.M. et al. "Estudo do comportamento espectral da clorofila e dos sólidos em suspensão nas águas do lago grande de Curuai (Pará), na época da seca, através de técnicas de espectroscopia de campo". Anais XII Simpósio Brasileiro de Sensoriamento Remoto, Goiânia, INPE, 2005, pp. 2447-2456.

OLMANSON, L., BREZONIK, P.I., BAUER, M.E.“Airborne hyperspectral remote sensing to assess spatial distribution of water quality characteristics in large rivers: The Mississippi River and its tributaries in Minnesota". Remote Sensing of Environment, 130, 2013, pp. 254-265.

PALMER, S.C.J.; KUTSER, T; HUNTER, P.D. "Remote sensing of inland waters: Challenges, progress and future directions."RemoteSensingofEnvironment, 157, 2015, pp.1-8.

PEREIRA, M. C. B; SCROCCARO, J. L. "Bacias Hidrográficas do Paraná". Secretaria de Estado do Meio Ambiente e Recursos Hídricos - SEMA. Curitiba, 2010.

PEREIRA, A. C. de F. 'Water Quality Researches: Spectral Variability Of The Water Body Analysis To Define A Sampling Scheme”.BrazilianJournalofCartography, Rio de Janeiro, No 67/5, 2015, pp. 1017-1024.

PEREIRA, A.C.F."Desenvolvimento de método para inferência de características físicas da água associadas às variações espectrais. Caso de Estudo: Reservatório de Itupararanga/SP”. Tese (Doutorado em Ciências Cartográficas) Unesp - Presidente Prudente, 2008, 206 p.

PMSB - Plano Municipal de Saneamento Básico Relatório de Diagnóstico da Situação do Saneamento de Londrina -PR. 2008.

R Core Team (2018). R: A language and environment for statistical computing.RFoundation for Statistical Computing, Vienna, Austria.

https://www.Rproject.org/.

REYNOLDS, C. S.“The ecology of freshwater phytoplankton”. Cambridge University Press, 1984.

ROESSLER, S. et al."Multispectral remote sensing of invasive aquatic plants using RapidEye”. In: Krisp, J. Meng, L., Pail, R., Stilla, U. (Eds.), 
Earth Observation of Global Changes (EOGC). Springer, Berlin, Heidelber, 2013, pp. 109-123.

RUNDQUIST, D. C.; LUOHENG, H.; SCHALLES, J. F.; PEAKE, J. S. “Remote measurement of algal chlorophyll in surface waters: the case for first derivative of reflectance near $690 \mathrm{~nm}$ ". Photogrammetric Engineering \& Remote Sensing, v. 62, n. 2, 1996, pp. 195-200.

SANDER DE CARVALHO, L.A., BARBOSA, C.C.F., NOVO, E.M.L.M., RUDORFF, C.M. "Implications of scatter corrections for absorption measurements $n$ optical of Amazon floodplain lakes using the Spectral Absorption and Attenuation Meter (AC-S-WETLabs)." Remote Sensing of Environment, 157, 2015, pp. 123-137.

SCHALLES, J.; YACOBI, Y.Remote detection and seasonal patterns of phycocyanin, carotenoid and chlorophyll pigments in eutrophic waters.Arch. Hydrobiol. Spec.Issues. Advanc. Limnol. 55, 2000, pp. 153168.

SILVA, A.R. Métodos de análise multivariada em R. 1ed. Piracicaba: EditoraFealq, 2016.

SIMIS, S.G.H., PETERS, S.W.M., GONS, H.J."Remote sensing of the cyanobacterial pigment phycocyanin in turbid inland water". Limnology and Oceanography, 50(1), 2005, pp. 237-245.

THOMPSON, S.K. “Sampling”. New York: John Wiley \& Sons, Inc. 2nd edition, 2002, 367p.

TUNDISI, J. G., and MATSUMURA-TUNDISI, T."Integration of research and management in optimizing multiple uses of reservoirs: the experience in South America and Brazilian case studies". Aquatic Biodiversity, 2003, pp. 231-242.

WEAVER, E. C.; WRIGLEY, R.“Factors affecting the identification of phytoplankton groups by means of remote sensing".Moffet Field: NASA, 1994, 124p.

VERPOORTE, C., KUSTER, T., SEEKEL, D.A., TRANVIK, L.J.“A global inventory of lakes based on high-resolution satellite imagery". AGU Publications, Geophysical Research Letters, 41, 2014, pp.6396-6402. 
Rev. Bras. de Cartografia, vol. 70, Special Issue "XIX Brazilian Syposium on GeoInformatics", 2018. pp. 1802 - 1822. 